\title{
STUDY OF GROWTH PARAMETERS AND GERMINATION ON TOMATO SEEDLINGS WITH DIFFERENT GROWTH MEDIA
}

\author{
P. VIVEK ${ }^{1} \&$ V. M. DURAISAMY ${ }^{2}$ \\ ${ }^{I}$ Research Scholar, Department of Farm Machinery and Power, Agricultural Machinery \\ Research Centre, AEC \& RI, TNAU, Coimbatore, Tamil Nadu, India \\ ${ }^{2}$ Professor, Department of Farm Machinery and Power, Agricultural Machinery \\ Research Centre, AEC \& RI, TNAU, Coimbatore, Tamil Nadu, India
}

\begin{abstract}
Tomato (Lycopersicon esculentum L.), from family solanaceae is a popularly cultivated vegetable in the world, and is famous for its nutritive and medicinal values.There are some shortcomings in the traditional transplanting such as low productivity, poor quality, high cost and also sometimes farmers face problems to raise tomato seedlings in due time to adverse environmental conditions. This technique has the potential to use in adverse condition and ultimately facilitates the production of vegetable seedlings in time with low cost, high productivity and good quality seedlings. Hence, this study was undertaken to evaluate the effect of different age of seedlings with growth media on seed germination and production of healthy vegetable seedling. Tomato seedlings were considered as the transplanting object to study the growth parameters with different aged seedlings and growth media. Tomato seedlings of 20, 25 and 30 days age were used for observation. The seedlings were grown in portray $(17 \times 13=221$ cells $)$ with three different growth media viz. coir pith (M1), vermin compost (M2) and coir pith + vermin compost (4:1) (M3). A completely randomized design (CRD) with three repetitions was used. Data were subjected to analysis of variance (ANOVA). Results revealed significant differences ( $p>0.05)$ in seedling growth parameters among the three growing media. The maximum growth parameters (shoot length, root length, stem diameter and no. of leaves) were observed at30 days aged seedlings in coir pith. The minimum growth parameters were observed in vermin compost for the same day of age seedlings. The maximum germination was found to be 99 per cent with coir pith. Hence, coir pith was found as optimum growth media for growing of tomato seedlings.

KEYWORDS: Protray, Growth Media, Age of Seedlings, Growth Parameters and Germination Percentage
\end{abstract}

Received: May 11, 2017; Accepted: Jun 03, 2017; Published: Jun 14, 2017; Paper Id.: IJASRJUN201759

\section{INTRODUCTION}

After China, India is the second largest producer of vegetables in the world. About 175 types of vegetables are grown in India, including 82 field vegetables and 41 roots (tuber and bulb) crops in India produces 14 per cent $(146.55 \mathrm{M} \mathrm{t})$ of world's vegetables from 15 per cent (8.5 M ha) of world area under vegetables. Productivity of vegetables in India $\left(17.3 \mathrm{t} \mathrm{ha}^{-1}\right)$ is less than the world average productivity $\left(18.8 \mathrm{t} \mathrm{ha}^{-1}\right)$ in 2012 2013. Most of the vegetables like tomato (Solanum lycopersicum), and peppers (Capsicum spp.) are first sown in nursery beds and later transplanted manually either on the ridges or on a well prepared seedbed (Patil, 2015). Tomato (Solanu lycopersicum L.) is a high-value vegetable crop that is widely consumed fresh or processed and grown in almost every country of the world. The increase in the area of production and value has increased the economic significance of the crop worldwide (Albahoet al., 2009).

The tomato is an annual plant, in the Solanaceae family, typically growing to $1000-3000 \mathrm{~mm}$ tall, with a 
weakly woody stem that usually scrambles over other plants. The fruit is edible; brightly colored (usually red, from the pigment lycopene) its diameter ranges between $10-20 \mathrm{~mm}$ in wild plants and cultivated forms. Botanically, it is a berry, with a subset of fruits. Furthermore, the tomato fruit is of nutritional importance with essential food value. In South Sudan, the tomato is grown under rain fed conditions, however, in Double Harvesting Farm drip irrigation was used to supplement the rainfall.

The production of healthy and vigorous tomato seedling is the most important factor in successful production and yield of tomato fruits. Germination of the seed is a critical stage, because the rest of the plant life is directly dependent upon the rate of its germination (Qadir and Shahzadi, 1969). Growth medium is known to have an effect on value of potted ornamental plants and plays an important role in germination rate, and many other physiological parameters including plant height, number of leaves, spike length, number of florets per spike, spike diameter and yield, etc. (Vendrame et al., 2005).

The best growing media should have proper aeration, water holding capacity and adequate nutrition supply; different manures provide good nutrition to plants when applied in combination with soil less substrates (Khobragade et al., 1997: Hartmann et al., 2011). Different vegetative and reproductive growth parameters produced best results favoured by different soil less media are observed in rose (Ahmad, 2004). Neelam et al., (2001) conducted an experiment in response of Eucalyptus comaldulensis seedlings in different soil media and found the maximum plant height (904.11 mm), number of leaves per plant (31.89) and stem thickness $(5.21 \mathrm{~mm})$ were observed in silt +clay media.

Mohammad et al., 2014, evaluated the seed germination and seedling growth of tomatoes as affected by different organic fertilizers. There were five treatments viz. trichocompost, vermi-compost, kitchen waste composts, cow dung based bio-slurry and control (soil). Treatments significantly influenced the germination and seedling growth. The germination percentage and co-efficient of germination were significantly higher in trichocompost which was identical with vermin compost and cow dung based bio-slurry but different from kitchen waste compost and control, Similarly the seedling growth characters like root length, shoot length, number of leaves, number of roots, fresh and dry weight of 10 seedlings and effectiveness against damping off disease were significantly highest in trichocompost media, which reflected on higher vigour index in the same treatment. However, there was no significant variation among the treatments in respect of root and shoot length ratio. The results suggest trichocmpost and vermin compost are suitable for raising healthy seedlings in organic tomato production.

Compared to traditional nursery bed, seedlings that are raised using portray germinate early and are vigorous. There is good root development in the seedling. Low mortality rates of the seed is observed that are sown in protray. Protrays are presently used for growing most of the vegetables and all kinds of flowers. The plugs are filled with a cohesive medium, and are eventually transplanted into other growing systems. Seeds are sown manually into plug trays. Only one plant is raised per cell. The protray grown transplant has been widened to provide a stable supply of high quality seedlings and improved transplanting efficiency (Jeong, 1992).

There are some shortcomings in the traditional transplanting such as low productivity, poor quality, high cost and also sometimes farmers face problems to raise tomato seedlings in time due to adverse environmental conditions. This technique has the potential to use in adverse condition and ultimately facilitates the production of vegetable seedlings in time with low cost, high productivity and good quality seedlings. Hence, this study was undertaken to evaluate the effect of different growth media on seed germination and production of healthy tomato seedling. 


\section{MATERIALS AND METHODS}

\section{Description of Study Site}

All plants used in the experiments were grown in plug type protray in the greenhouse. Tomato seedlings were considered as the transplanting object to study the physical properties of vegetable seedlings and to determine the suitable growth media.The study was conducted in a 100 per cent net shade house at the Tamil Nadu Agricultural University. The University is located between latitude $11^{\circ} 07^{\prime} 47^{\prime \prime} \mathrm{N}$ and longitude $76^{\circ} 55^{\prime} 59^{\prime \prime}$ E and elevated 2, 56,000mm above mean sea level.

\section{Nursery Growing Materials}

Conventionally, the farmers practice transplanting of 25 to 30 days old plug seedling. Hence three levels of 20,25 and 30 days old seedlings were planned (Mohammad et al., 2014).Growing media have three main functions: 1) provide aeration and water, 2) allow for maximum root growth and 3) physically support the plant. Growing media should have large particles with adequate pore spaces between the particles (Bilderback et al., 2005). Appropriate particle size selection or combination is critical for a light and fluffy (well-aerated) medium that promotes fast seed germination, strong root growth and adequate water drainage.

Many researchers conducted study on different growth media. Mohammad et al., 2014 studied three different growth media such astrichocompost, vermin compost and kitchen waste compost. Muhammad et al., 2016 experimented with peat, compost and traditional practicing media in 1:1:1 ratio for tomato seedlings.Peter et al., 2015 conducted study with (Farm Yard Manure- FYM, compost, canal silt, FYM + compost, FYM + canal silt, compost + silt and FYM + compost +silt for producing tomato seedling in green house nursery.

The protrays are available in the market in different sizes and shapes. The cells are in round, square and truncated inverted pyramid shapes. The trays contain 128, 200 or 288 cells in which the arrangement of cells is $8 \times 16,10 \mathrm{x} 20$ and $12 \times 24$. The most popular one being used in India has 14 x 7 or 17 x 13 cells.In this study the seedlings were grown in (17 $\mathrm{x} 13$ ) protray with three different growth media such viz. coir pith (M1), vermicompost (M2) and coir pith + vermicompost (4: 1) (M3).

\section{Protray Vegetable Seedlings Preparation}

The well decomposed coir pith and vermicompost was used as media for raising the tomato seedlings. The media was filled half of each cell in the tray. Single seed was kept in each cell of the protray (Figure 1) and trays were completely filled with media. The tray seedlings are grown under controlled environments and have appreciable vitality and plant stand after transplantation. It is reasoned that all the vital inputs to the growing seedling are rendered precisely in a regulated way so as to allow them to acquire these attributes. Based on the moisture content of media, watering to the seedlings was done in the evenings for the subsequent 15 days using rose cans. After 4 to 5 days, the seed sprouted with two leaves, application of water was increased gradually depending on moisture level in trays. Simultaneously, germination per cent of seedlings with different growth media were calculated using the following formula (Atifet al., 2016). 

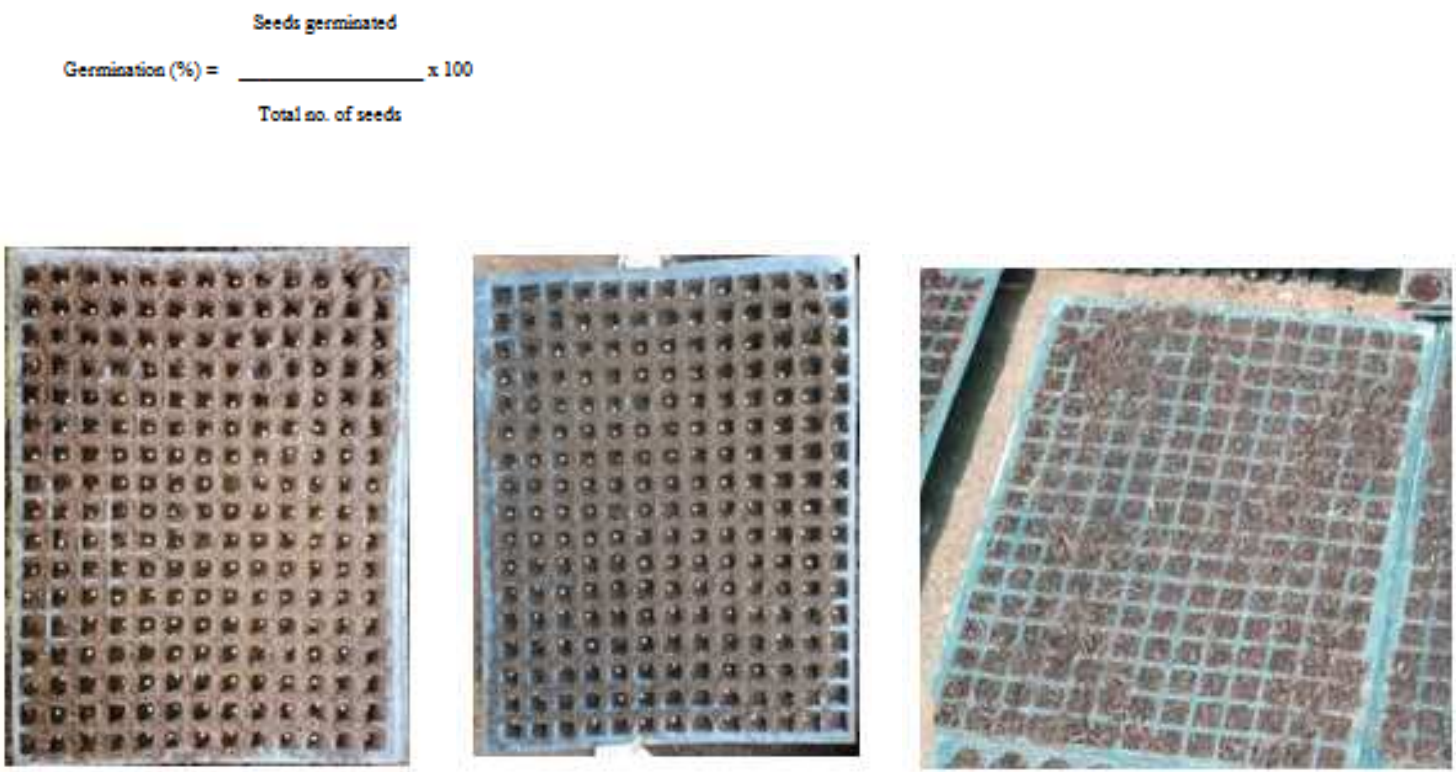

Figure 1: Tomato Seedlings Grown in Protray with different Growth Media (a. Coir Pith, b. Vermicompost c. Coir Pith + Vermicompost (4:1))

\section{Growth Parameters}

After 20 days, the growth parameters viz., number of leaves, shoot length $(\mathrm{mm})$, root length (mm) and stem diameter (mm) were measured (Figure 2). The seedlings were removed manually from the protray cells, and the shoot and root length of the seedlings was recorded with a steel rule with least count of $0.5 \mathrm{~mm}$. The stem diameter was measured using a digital vernier caliper with least count of $0.02 \mathrm{~mm}$. The measurements were taken for 20, 25 and 30 day old tomato seedlings. The tomato seedlings grown in coir pith media are shown in Figure 3.

\section{Experimental Design}

The main purpose of this experimental design was to determine the effect of influencing variables on growth characteristics and germination per cent with different growth media. The study was laid out in a completely randomized design (CRD) with three treatments repeated four times. Data was subjected to Analysis of Variance (ANOVA) using analytical software (2003). Where, a significant F-test was used and means comparison tests carried out using Least Significant Difference (LSD) at $\mathrm{p} \leq 0.05$. The results were expected to optimize the variables to achieve maximum germination of plug seedlings with appropriate growth media.

Tomato seeds SS-106 variety [Sankranthi seeds Pt. Ltd., India], were sown one in each plug/cell into 221 cells of trays [Greens Net Marketing Pt. Ltd., India] filled with the different growth media. Seedling emergence was determined on all the 221 cells of a tray. Thereafter, growth and development parameters were measured using twenty five (25) randomly tagged seedlings from each repetition throughout the study. 

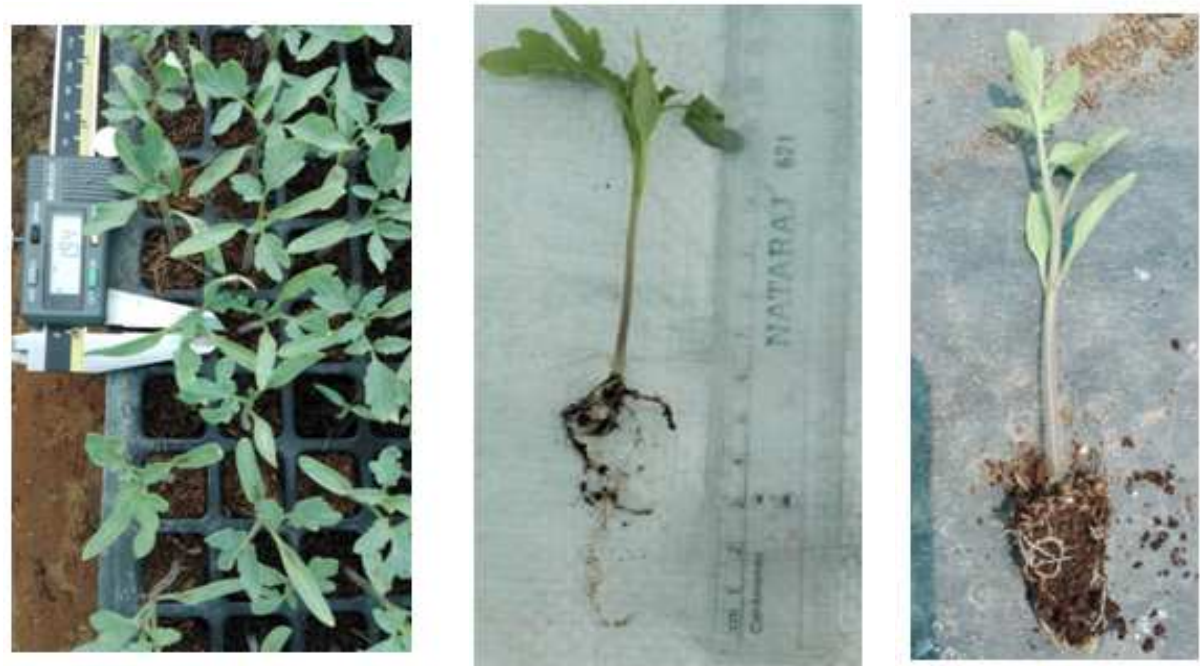

Figure 2: Measurement of Growth Parameters with Growth Media (Coir Pith)
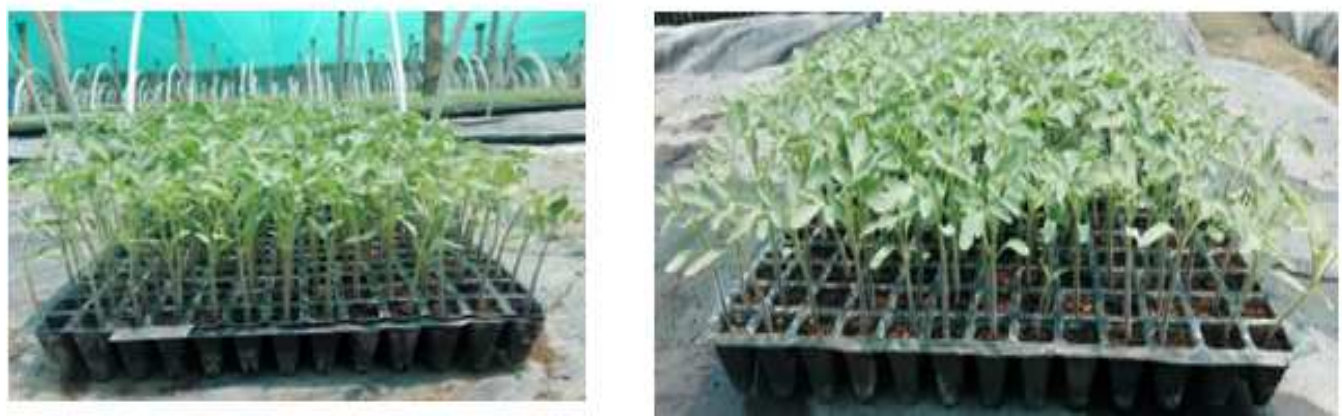

Figure 3: Tomato Seedlings Grown in Portray with Coir Pith Media

\section{RESULTS AND DISCUSSIONS}

\section{Germination Percentage with Different Growth Media}

Growing media influences seed germination, succeeding emergence and growth of seedlings in a nursery (Baiyeri and Mbah, 2006) because it is a reservoir of moisture and plant nutrients (Grower, 1987). In addition, it influences the performance of seedling before they are transplanted in the field (Adediran, 2005). In this study, seedling germination percentage was calculated after four days of sowing in protray with different growing media. The calculated germination percentages are shown in Table 1. The maximum germination was found to be 99per cent with coir pith. The minimum germination as observed at 87 per cent with vermin compost.

Table 1: Germination Percentage on Different Growth Media

\begin{tabular}{|c|l|c|}
\hline S. No & \multicolumn{1}{|c|}{ Growth Media } & Germination (\%) \\
\hline 1 & Coir pith, M1 & 99 \\
\hline 2 & Vermi compost, M2 & 87 \\
\hline 3 & Coir pith + Vermi compost, M3 & 92 \\
\hline
\end{tabular}

\section{Effect of Growth Media on Shoot Length}

The shoot length of seedlings at three different ages with different growth medium was observed.The age of seedlings such as 20 (A1), 25 (A2) and 30 (A3) days and growth media such as coir pith (M1), vermicompost (M2) and 
coir pith + vermin comoost (4:1) (M3) has influenced the shoot length of tomato seedlings.At all ages of seedlings, the highest shoot length was observed in the growth medium of coir pith.The maximum shoot length $(89.3 \mathrm{~mm})$ was recorded in coir pith with 30 days aged seedlings. The minimum shoot length $(82.9 \mathrm{~mm})$ was recorded in vemi compost with 30 days aged seedlings. The treatment combination of different age of seedlings and growth media was significant at $5 \%$ level (Table 2).

Table 2: Analysis of Variance on Shoot Length

\begin{tabular}{|l|c|c|c|c|c|c|}
\hline \multicolumn{1}{|c|}{ Source } & DF & $\begin{array}{c}\text { Sum of } \\
\text { Square }\end{array}$ & F Value & CD (0.05) & $\begin{array}{c}\text { Standard Error of } \\
\text { a Difference }\end{array}$ & PROB \\
\hline Total & 26 & 825.93 & 146.86 & & & \\
\hline Treatment & 8 & 822.03 & 475.06 & & & $0.015 *$ \\
\hline Age (A) & 2 & 747.76 & 1725.55 & 0.46 & 0.22 & $0.000 * *$ \\
\hline Medium (M) & 2 & 46.20 & 106.80 & 0.46 & 0.22 & $0.000 * *$ \\
\hline A x M & 4 & 28.07 & 32.44 & 0.80 & 0.38 & $0.003 * *$ \\
\hline
\end{tabular}

$\mathrm{CV}=0.24 \%$

Similar result was reported by Abad et al., (2002) and Awang et al., (2009) working on seedlings growing with coir pith and manures. Coir pithwas a good growth media with acceptable $\mathrm{pH}$, electrical conductivity and other chemical attributes. It has thevirtuous oxygen diffusion and provide support to fast grown of the seedlings due to availability of better nutrition with water in root zone of seedlings when compare with vermicompost.

Combined application of coir pith and vemi compost in the treatment showed significant effect on seedlings growth parameters, due to the synergistic combination of both factors in improving the physical conditions of the media and nutritional factors (Sahni et al., 2008). This result was parallel to the finding of Campos Mota et al., (2009) and Abirami et al., (2010) who suggested that since coir dust is low in nutrients when mixed with vermin compost, provides a better growth medium for plant establishment. However, the air filled porosity (AFP), easily available water (EAW) and aeration media were not at the recommended level which in turn limit the root growth and lowered the water holding capacity. Therefore, the media coir pith alone was more suitable than vermin compost with coir pith because of the better physical properties and enhanced nutrient level.

\section{Effect of Growth Media on Root Length}

The root length was one of the influenced growth parameter with different age of seedlings and growth media. 30 days aged seedling has a highest root length of $37.9 \mathrm{~mm}$ was recorded in coir pith, whereas the minimum root length (34 $\mathrm{mm}$ ) was observed with vermin compost. The treatments were $(\mathrm{p}=5 \%)$ significantly difference with each other (Table 3$)$. This is due to variation of available nutrients in the selected growth media.

Table 3: Analysis of Variance on Root Length

\begin{tabular}{|l|c|c|c|c|c|c|}
\hline \multicolumn{1}{|c|}{ Source } & DF & $\begin{array}{c}\text { Sum of } \\
\text { Square }\end{array}$ & F Value & CD (0.05) & $\begin{array}{l}\text { Standard Error } \\
\text { of a Difference }\end{array}$ & PROB \\
\hline Total & 26 & 140.23 & 37.82 & & & \\
\hline Treatment & 8 & 137.66 & 120.68 & & & $0.041^{*}$ \\
\hline Age (A) & 2 & 30.98 & 108.66 & 0.37 & 0.17 & $0.000 * *$ \\
\hline Medium (M) & 2 & 102.45 & 359.25 & 0.37 & 0.17 & $0.000 * *$ \\
\hline A x M & 4 & 4.22 & 7.40 & 0.64 & 0.30 & $0.039 *$ \\
\hline
\end{tabular}

$$
\mathrm{CV}=0.72 \%
$$


So, egiman (1982) reported that vermin compost provides adequate nutrient and enhances both physical properties and water holding capacity to growing of seedlings. However, it holds too much water which affects aeration within the growth media, thus affecting the oxygen diffusion to the roots which probably occurred in this study.

\section{Effect of Growth Media on Stem Diameter}

The stem diameter was also influenced by the age of seedlings and growth media. The ANOVA on stem thickness are shown in Table 4. It was quite high in 30 days old seedlings (A3) with growth media of Coir pith (M1) having the maximum thickness of $1.77 \mathrm{~mm}$. The minimum stem thickness (1.08 mm) was found in same days of seedling (A3) with growth media (M1). The interactions treatment was also significant at 5 per cent level. The interactions were also significant explaining that the response was not uniform in all media as influenced by the age. Similar results were reported by Singh et al., 2007. As the plant height was increases automatically the stem thickness was also increased, however is shown (Table 4) to be statistically significant.

Table 4: Analysis of Variance on Stem Diameter

\begin{tabular}{|l|l|c|c|c|c|c|c|}
\hline \multicolumn{1}{|c|}{ Source } & DF & $\begin{array}{c}\text { Sum of } \\
\text { Square }\end{array}$ & F value & CD (0.05) & $\begin{array}{c}\text { Standard } \\
\text { Error of a } \\
\text { Difference }\end{array}$ & PROB \\
\hline Total & 26 & 1.73 & 20.94 & & & \\
\hline Treatment & 8 & 1.67 & 65.83 & & & $0.034 *$ \\
\hline Age (A) & 2 & 0.45 & 71.75 & 0.055 & 0.026 & $0.001 * *$ \\
\hline Medium (M) & 2 & 1.09 & 171.88 & 0.055 & 0.026 & $0.000 * *$ \\
\hline $\mathbf{A ~} \mathbf{x} \mathbf{M}$ & 4 & 0.12 & 9.83 & 0.096 & 0.046 & $0.024 *$ \\
\hline
\end{tabular}

$\mathrm{CV}=4.97 \%$

\section{Effect of Growth Media on Number of Leaves}

The number of leaves was found to be high in 30 days old seedlings (A3) grown in the media of coir pith (M1) and the minimum number of leaves were found in vermin compost on same day of seedlings. Age of seedlings, grown medium and interaction variables were also significant at 5 per cent level. These results were supported by the findings of Raiz et al.,(2008) who counted maximum number of leaves in leaf compost mixture. The possible reason was nutritional contribution of the treatment that produced maximum number of leaves. The result of effected growth parameters on different age of seedlings and growth media are shown in Table 5.

Table 5: The Result Related to Growth Parameters with Different Aged Seedlings and Growth Media

\begin{tabular}{|l|l|c|c|c|c|}
\hline S. No. & Treatments & $\begin{array}{c}\text { Shoot } \\
\text { Length } \\
(\mathbf{m m})\end{array}$ & $\begin{array}{c}\text { Root } \\
\text { Length } \\
(\mathbf{m m})\end{array}$ & $\begin{array}{c}\text { Stem } \\
\text { Diameter } \\
(\mathbf{m m})\end{array}$ & $\begin{array}{c}\text { No. of } \\
\text { Leaves }\end{array}$ \\
\hline 1 & A1M1 & 74.8 & 35.6 & 1.23 & 2 \\
\hline 2 & A1M2 & 73.0 & 30.1 & 0.89 & 1 \\
\hline 3 & A1M3 & 73.5 & 32.7 & 1.02 & 2 \\
\hline 4 & A2M1 & 80.1 & 36.5 & 1.46 & 3 \\
\hline 5 & A2M2 & 78.7 & 31.8 & 1.05 & 2 \\
\hline 6 & A2M3 & 79.0 & 33.8 & 1.12 & 3 \\
\hline 7 & A3M1 & 89.3 & 37.9 & 1.77 & 4 \\
\hline 8 & A3M2 & 82.9 & 34.0 & 1.08 & 3 \\
\hline 9 & A3M3 & 87.6 & 34.4 & 1.26 & 4 \\
\hline 10 & Mean & 79.9 & 34.1 & 1.21 & 3 \\
\hline
\end{tabular}




\section{CONCLUSIONS}

Among the three different growth media, coir pith was a good growth media with acceptable $\mathrm{pH}$, electrical conductivity and other chemical attributes. It has the virtuous oxygen diffusion and provides support to fast growth of the seedlings due to availability of better nutrition with water in root zone of seedlings. Combined application of coir pith and vemi compost in the treatment showed significant effect on seedlings growth parameters due to the synergistic combination of both factors in improving the physical conditions of the media and nutritional factors (Sahni et al., 2008). However, the air filled porosity (AFP), easily available water (EAW) and aeration media were not at the recommended level, which in turn limit the root growth and lowered the water holding capacity. Therefore, the media coir pith alone was more suitable than vermicompost with coir pith because of the better physical properties and enhanced nutrient level. Results revealed significant differences $(\mathrm{p}>0.05)$ in seedling growth parameters among the three growing media. The maximum growth parameters such as shoot length, root length, stem diameter and no. of leaves $(89.3 \mathrm{~mm}, 37.9 \mathrm{~mm}, 1.77 \mathrm{~mm}$ and 4$)$ were observed at 30 days aged seedlings with coir pith media. The minimum growth parameters $(82.9 \mathrm{~mm}, 34 \mathrm{~mm}, 1.08 \mathrm{~mm}$ and 3 respectively) were observed with vermicompost for the same day of aged seedlings. The maximum germination was found to be 99 per cent with coir pith and the minimum was 87per cent in vermin compost. Hence, coir pith was found as suitable growth media for growing of tomato seedlings.

\section{REFERENCE}

1. Abad M, P. Noguera, R. Puchades, A. Maquieira and V. Noguera. 2002. Physico-chemical and chemicalproperties of some coconut dusts for use as a peatsubstitute for containerized ornamental plants.Bio-resource Technology.82(3), 241 - 245.

2. Abirami K, J. Rema, P.A. Mathew, V. Srinivasan and S. Hamza. 2010. Effect of different propagation media on seed germination, seedling growth and vigour of nutmeg (Myristica fragrans Houtt.). J. Med. Plants Res. 4:2054-2058.

3. Adediran J.A. 2005. Growth of tomato and lettuce seedlings in soilless media. Journal of Vegetable Science. 11(1):5-15.

4. Ahmad M, M.F Khan, A. Hamid and A. Hussain.2004. Effect of urea, DAP and FYM on growth and flowering of Dahlia (Dahlia variabilis). Int. J. Agric. Biol. 6:393-395.

5. Albaho, M., N. Bhat, H. Abo-Rezq and B. Thomas. 2009. Effect of three different substrates on growth and yield of two cultivars of Capsicum annuum. Eur. J. of Sci. Res., 28(2): 227-233.

6. Atif, M. J., G. Jellani, M. H. A. Malik, N. Saleem, H. Ullah, M. Z.Khanand S. Ikram. 2016. Different Growth Media Effect the Germination and Growth of Tomato Seedlings. Science, Technology and Development. 35(3), 123-127.

7. Awang Y, A.S Shaharom, R.B Mohamad, A. Selamat. 2009. Chemical and physicalcharacteristics of cocopeat-based media mixtures andtheir effects on the growth and development ofCelosia cristata. American Journal of Agriculturaland Biological Sciences.4(1), 63- 71 .

8. Baiyeri K.P and B.N Mbah. 2006. Effects of soilless and soil-based nursery media on seedling emergence, growth and response to water stress of African breadfruit (Treculia africana Decne). African Journal of Biotechnology.5(15):1405- 1410.

9. Bilderback T.E, S.L Warren, J.S Owen Jr, and J.P Albano. 2005. Healthy substrates need physicals too. Hort. Technology. 15(4), 747- 751.

10. Campos Mota L, U. Van Meeteren and C. Blok. 2009. Comparison of physical properties of vermicompost from paper mill sludge and green compost as substitutes for peat based potting media. Acta Hortic. 819:227-234. 
11. Grower S.T. 1987. Relations between mineral nutrient availability and fine root biomass in two Costa Rican tropical wet forests. Hypothesis Biotropica. 19 (2):171- 175.

12. Hartmann H.T, D.E. Kester, F.T. Davies and R.T. Geneve.2011. Hartmann and Kester's Plant propagation: principles and practices ( $8^{\text {th }}$ Edition). Prentice Hall, Boston, USA. Pp 825.

13. Jeong, B.R. 1992. The use of plug transplants in Korea. Division of Plant Resource and The environment, College of Agriculture, Gyeongsang National University, Chinju, Korea. PP. 1 - 9

14. Khobragade R.I, M.M.Damke and B.J. Jadhao (1997). Effect of planting time and spacing on growth, flowering and bulb production of tuberose (cv. Single). Acta Horticulturae. 21:4447.

15. Lia. X, Y. Cai and Y Wang. 2015. Experiment on physical and mechanical properties of tomato seedling pot for automatic vegetable transplanter. J of Zhejiang Uni.41(5): 616-622.

16. Mohammad K.A, A.R Mohammad, M.D. Habibur Rahman and M.D. Jahiruddin. 2014. Effects of organic fertilizers on the seed germination and seedling vigour of tomato. Proceeding of $4^{\text {th }}$ ISOFAR scientific conference. 'building organic bridges', at the organic world congress. 13-15 Oct., Istanbul, Turkey.

17. Muhammad Jawaad Atif, Ghulam Jellani, Muhammad Humair Ahmed Malik, Noor Saleem, Hidayat Ullah, Muhammad Zameer Khan and Samia Ikram. 2016. Different Growth Media Effect the Germination and Growth of Tomato Seedlings.Science, Technology and Development 35 (3): 123-127.

18. Neelam A and M Ishtiaq (2001). Response of Eucalyptus camaldulensis seedlings to different soil media. Sarhad Journal of Agriculture.17(1): 75-79.

19. Patil, S.Amruta, Sushil S. Davane, and Sagar V. Malunjkar. 2015. Design, Development and Testing of Hand Held Vegetable Transplanter. Int. J of Advanced Res. 3(1): 247-253.

20. Peter B. S. Gama, Lubajo Bosco Wani, Philip Wani Marcelo-d'Ragga and Beatrice C. Misaka. 2015. Effect of Soil Media on Growth of Tomato Seedlings under nursery (Greenhouse) Conditions. International Journal of Agricultural Research and Review: ISSN-2360-7971. 3(10). 432-439.

21. Qadir S.A, Shahzadi H.N 1969. Seed germination of common cultivated trees, shrubs and some wild grass. Pakistan Journal Forestry. 19:195-220.

22. Raiz A, M. Arshad, A. Younis, A. Raza and M. Hameed. 2008. Effect of different growing media on the growth and flowering of Zinnia elegans cv. Blue point. Pakistan Journal Botany.40:1579-1585.

23. Sahni S, B.K. Sharma, D.P. Singh, H.P. Singh and K.P. Singh. 2008. Vermicompost enhances performance of plant growth promoting rhizobacteria in cicer arietinum rhizosphere against sclerotium rolfsii. Crop prot. 27:369-376.

24. Singh, B., H.L. Yadav, M. Kumar., and N.P.S. Sirohi. 2007. Effect of plastic plug tray cell size and shape on quality of soilless media grown tomato seedling. ActaHorticulturae. 742: 57 - 60.

25. Soegiman 1982. The nature and properties of soil. Bucman and Brady. Bhatara Karya Aksara. Jakarta. 788 hal.

26. Sterrett, S.B., 2001. Compost as Horticultural Substrates for Vegetable Transplant Production. In: Compost Utilization in Horticultural Crooping Systems, StoVella, P.J. and B.A. Kahn (Eds.). Lewis Publication, Boca Raton, FL, pp: 227-240.

27. Vendrame A.W, I. Maguire and K.K. Moore. 2005. Growth of selected bedding plants as effected by different by different compost percentages. Florida State Hort.Soc. 18:368-371. 
